\title{
Immigration could strain EU health services
}

Physicians and politicians are warning that the new European Union membership of former East Bloc countries with high rates of infectious diseases could strain the continent's public health resources.

In May, 10 countries, many of them former Communist states, joined the EU, sparking an intense debate over the prospect of increased demand for health services across the continent.

Under the EU's Charter of Fundamental Rights, adopted in 2002, all patients have the right to treatment in any member state. A series of European Court of Justice rulings have also confirmed that patients having trouble receiving care in their home country may seek treatment in another EU state. Their home government is required to reimㄱ burse the costs.

As of June 1, a new European health insurance card also made it easier for EU citizens to access care while they are travelling or working temporarily in another EU country.

These rights mean patients may seek treatment outside their country's borders.

Improving the health status of former Soviet bloc countries will be a "major challenge," warned David Byrne, the European commissioner for health and consumer protection.

"With EU enlargement, our borders will shift to the East," Byrne said. "Russia, Ukraine, Belarus and others will soon be on our doorstep and will require even greater attention. We need to persuade our partners that preventing HIV/AIDS is just as vital to their future economic well-being as roads or power stations."

Doctors from the European Centre on Health Societies in Transition and the Imperial College London joined the warning chorus in April (Lancet 2004;363:1389-92), stating that "public health systems, rooted in Soviet traditions, are struggling to respond effectively" to diseases such as tuberculosis and HIV.

Epidemics have been reported in Russia, Ukraine and Belarus countries that now border the
EU. In the paper, the doctors say movement within the EU raises questions about the possible spread of those diseases.

In Western Europe, widespread concern has centred around the prospect of this potential surge in immigration. In the UK, the lobby group Immigration Watch claims between 40000 and 50000 workers will move to the UK from the East each year, in part because of better quality health care. Official predictions put the likely immigration rate closer to 10000 per year.

In Eastern Europe, medical associations are worried higher wages in the West will prompt the mass emigration of doctors. [See adjacent article on the Czech Republic.]

Aware of the widespread confusion around patients' rights that these debates have stimulated, the EU Commission has established a high-level group of senior health officials from the member states to improve cooperation around the issue. - Colin Meek, Wester Ross, Scotland

\section{Human Resources}

\section{Czech Republic fears EU membership will lure doctors}

The Czech Republic's health insurance system is braced for an onslaught of new claims following the Eastern European country's entrance into the European Union in May.

Generally regarded as practising the highest standard of medical care in the former Eastern bloc, the Czech Republic is expected to be a mecca for patients from EU countries seeking better quality treatment $\approx$ than they can get at home.

"Middle class Russians or Arabs who want good care but can't afford the Mayo Clinic might ... [already] come to the Czech Republic," says Pavel Hrobon, a Czech physician and health administrator.
In addition, there will be a shift in the physician workforce. Czeck doctors' earn about 35000 crowns a month (Can\$1785) - a quarter of the average income for physicians in neighbouring Germany. Hrobon predicts that $5 \%$ of doctors will seek work elsewhere. But David Rath, head of the Czech Chamber of Doctors, estimates the exodus will reach $30 \%$.

Dr. Pavel Machac, an anesthesiologist at Prague's Nemocnice Hospital, says he is among those who will head West. "Here you are forced to work massive overtime even though it is against EU rules," says Machac. "I want to be in a

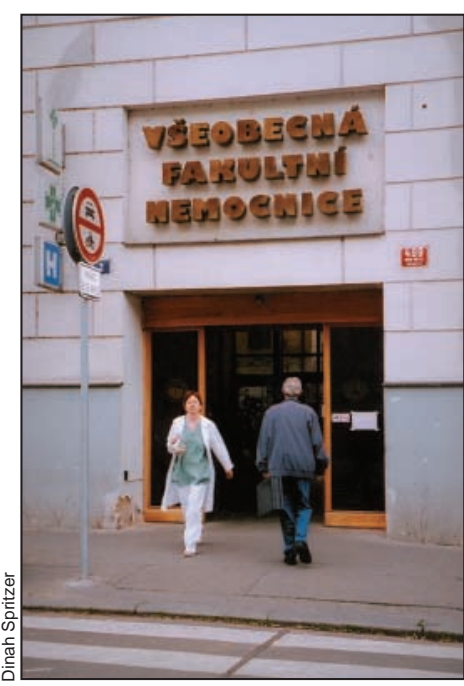

Open doors: Czech medical facilities may be inundated with patients from new EU members. 
country where I am treated more fairly."

Some specialists do work excessive hours due to an uneven distribution throughout the Republic.

Health Minister Jozef Kubinyi has attempted to quash fears of both a doctor shortage and an influx of patients. He points to the offsetting arrival of Slovak and Polish doctors who get paid more in the Czech Republic.

Patients will only be motivated to come to the Czech Republic for elective procedures, such as dentistry and plastic surgery, that they have to pay for out-of-pocket, he says.

The vast majority of Czech citzens are covered by the 9 public insurance companies. Private insurers supplement what is offered.

If patients do arrive from other Eastern bloc countries seeking Western-style medicine, they will also find a country with almost no waiting times for operations. There are only 330 people per doctor in the Czech Republic, compared to 650 people per doctor in Great Britain.

The country's 9 public health care insurers are the entity most likely to be affected by the country's entrance into the EU, since the families of workers from EU countries will now qualify for benefits, even if they are non-residents. Visitors requiring emergency care will also be covered. In addition, the government anticipates an influx of pensioners from Western Europe because of the Czech $\mathrm{Re}$ public's lower cost of living.

Ladilslav Svec, director of the Prague-based Center for International Reimbursements, said insurers will have to spend time and money "evaluating the concrete situation of concrete individuals," to determine if they meet residency requirements that entitle them to benefits.

Perhaps the most pressing problem, Svec says, is the 70 000 Slovaks working in the Czech Republic who will now be covered by Czech insurance

\section{Environmental Health}

\section{OCFP pesticide study triggered by complaint}

The Ontario College of Family Physicians' conclusion that there are no safe pesticide exposure levels, which garnered unprecedented national coverage, was sparked by a pesticide industry lobby group's insistence that there is not enough evidence to support such warnings.

The OCFP launched an extensive review of pesticide literature more than 18 months ago after Industry Task Force II on 2,4-D Research Data, a USbased group, complained that warnings of harmful effects of pesticides included in an OCFP information pamphlet were inaccurate. $(2,4-\mathrm{D}$ is the most common active ingredient in lawn care herbicides.)

The complaint was a repeat of the usual arguments in the ongoing debate on pesticides, which the head of the OCFP describes as "an exercise in finger point- ing," where one group cites a report warning of health effects and the other side cites another report indicating the results are inconclusive. The OCFP study was aimed at ending such discourse.

The study (www.ocfp.on.ca), funded by the non-profit Laidlaw Foundation, was not peer-reviewed or published. This is the first time a Canadian medical association has attempted to review the literature. Researchers examined 12000 studies on the health effects of pesticides and drew conclusions from the 250 studies deemed to have the most solid methodology.

The review found "consistent evidence" of serious health risks, including brain, kidney, and prostate cancer, and reproductive and nervous system effects. For example, $3 \%-7.7 \%$ of cases of non-Hodgkin's lymphoma are attributable to exposure to phe- companies. Those returning to live in Slovakia, also now an EU member, are entitled to Czech health coverage even after they permanently leave the Czech Republic.

Insurance companies are already infamous in the $\mathrm{Czech}$ Republic for not paying doctors on time, so some critics question whether they will have trouble reimbursing foreign hospitals when Czechs get ill while they are abroad.

"It's estimated that international clearing of payments between insurance companies in the enlarged EU will take an average of 3 years," says Hrobon.

The Czech healthcare sector is running a deficit of 10 billion crowns (Cdn\$52 million) and co-payments, as well as a closing of numerous hospitals, may be a necessity.

In such a bankrupt system, foreigners can expect to find well-educated doctors, but preventive care and even toilet paper are not always options. Dinah A. Spritzer, Prague noxyacetic acids and chlorophenols.

In addition, there was no evidence that some pesticides are less damaging than others. Rather, what differed were the effects and the time it

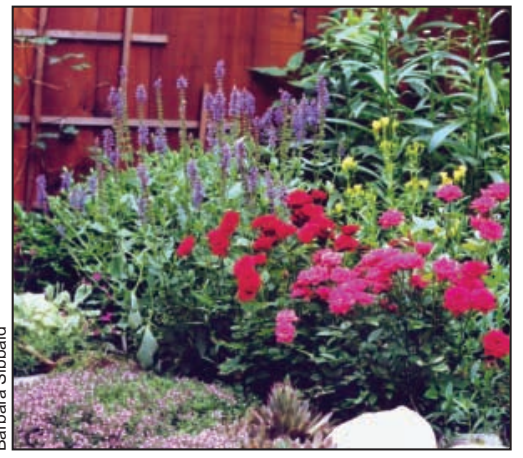

A pesticide-free Ontario garden. took for them to appear.

"Our study showed that family doctors are right in advising patients to avoid exposures," says Jan Kasperski, CEO of the OCFP.

But Donald Page, Executive Director of the Industry Task Force II, attacked the findings in the media and online, charging that the conclusions are based on a "biased review" with unclear criteria for study selection. - Pauline Comeau, Ottawa 